\title{
HEALTH AND PHYSIOLOGICAL POTENTIAL OF SOYBEAN SEEDS SUBMITTED TO DIFFERENT STORAGE CONDITIONS
}

\author{
Pastora Josefina Querales ${ }^{1}$, Victor Augusto Forti ${ }^{2}$, Vanessa Cristina Frare ${ }^{3}$, Taís Leite Ferreira \\ Pinto $^{4}$, Annelise Roberta Tremocoldi ${ }^{4}$, Heloisa Malaguetta ${ }^{5}$, Thaís Dias Martins ${ }^{4}$, Maria Heloisa \\ Duarte de Moraes ${ }^{4}$ \\ ${ }^{1}$ Universidad Centroccidental Lisandro Alvarado, Venezuela. E-mail: pastoraq@ucla.edu.ve \\ ${ }^{2}$ Universidade Metodista de Piracicaba - UNIMEP, Brasil. E-mail: viaugu@yahoo.com.br \\ ${ }^{3}$ BASF, Brasil. E-mail: vanessa.frare@basf.com \\ ${ }^{4}$ Escola Superior de Agricultura Luiz de Queiroz, Universidade de São Paulo, Brasil. E-mail: tais_leite@yahoo.com, \\ annetremocoldi@hotmail.com, tdiasm@gmail.com,mhdmorae@usp.br \\ ${ }^{5}$ Centro de Energia Nuclear na Agricultura, CENA, Brasil. E-mail: helo_malaguetta@hotmail.com
}

\section{SUMMARY}

The objective of this study was to verify the health and physiological potential of soybean seeds submitted to different storage conditions. The harmful effect of fungi on seed quality before storage was observed. Generally, there was a reduction in fungal occurrence with storage, principally for the conditions of the cold chamber and the uncontrolled laboratory environment, resulting in increasing germination and seedling emergence.

Palavras-chave: Field fungi, Glycine max, Storage fungi, Seed quality

\section{POTENCIAL SANITÁRIO E FISIOLÓGICO DE SEMENTES DE SOJA SUBMETIDAS A DIFERENTES CONDIÇÕES DE ARMAZENAMENTO}

\section{RESUMO}

O presente trabalho teve como objetivo verificar o potencial sanitário e fisiológico de sementes de soja submetidas a diferentes condições de armazenamento. Antes do armazenamento constatou-se o efeito negativo dos fungos na qualidade fisiológica das sementes. De maneira geral, com o armazenamento houve queda na incidência dos fungos, principalmente nos ambientes de câmara fria e em condições não controladas, refletindo na melhora da qualidade fisiológica.

Keywords: Fungos de campo, Fungos de armazenamento, Glycine max, Qualidade de sementes 


\section{INTRODUCTION}

Soybean [Glycine $\max (\mathrm{L}$.$) Merrill] is$ one of the crops which has most expanded in Brazil, reaching $90,025,000$ tons for the 2013/14 crop (CONAB, 2014). The use of high quality seed has been one of the factors which most contributed to the production increase.

After harvest, the seeds are dried, cleaned and stored until sowing. Storage of soybean seeds is practically obligatory (KROHN \& MALAVASI, 2004) because the harvest period, which is between January and May in Brazil, does not coincide with sowing, which starts in mid-September.

Storage is a key factor for seed producers and should be done under conditions which permit the physiological potential to be maintained until seeds are used (GALLI et al., 2007). The seeds longevity is affected by the seed initial quality and the storage conditions (CATÃO et al., 2013). If storage conditions are unfavorable, seed germination and vigor will be reduced and adversely affect crop development (MARCOS FILHO, 2005).

From the moment of their formation until storage, seeds serve as an important vehicle (ITO et al., 2003) to saprotrophic and pathogenic microorganisms (DOMINJAN et al., 2005) and can be infected by various fungi. There are two groups of fungi linked to seeds, those called field fungi and those called storage fungi (TANAKA et al., 2001).

In soybean, the field fungi include the genera Colletotrichum, Phomopsis, Cercospora and Fusarium, among others (RATHOD \& PAWAR, 2012; WAINTASSI et al., 2012). The association of these fungi with seeds occurs while these are still in the field, before harvest, and they can cause damage after sowing. These fungi do not affect seed physiological quality during storage because they only develop when seed moisture content is higher than $20 \%$ and relative humidity higher than $95 \%$ (DHINGRA, 1985; MARCOS FILHO, 2005). A reduction in seed moisture content halts development of the field fungi, and these may remain dormant or gradually die (DHINGRA, 1985).

On the other hand, the storage fungi, represented by the genera Aspergillus and Penicillium, can survive in low humidity environments and are able to proliferate in succession to the field fungi (TANAKA et al., 2001, RATHOD \& PAWAR, 2012, ANWAR et al. 2013). These genera can be present in low percentages in recentlyharvested seeds (TANAKA et al., 2001), but generally infect the seeds after harvest, 
causing more or less damage according to the temperature, relative humidity (MARCOS FILHO, 2005), seed moisture content and storage time (DHINGRA, 1985).

Storage fungi alter seed tissues, causing heat by respiration, consume of seed reserves, seed discoloration and mycotoxins production (MARCOS FILHO, 2005), resulting in seed deterioration (TANAKA et al., 2001).

A seed borne pathogen may be present externally, internally or associated with the seed as contaminant and may cause seed abortion, seed rot, seed necrosis, reduction of the germination capacity as well as seedling damage resulting in development of disease at large stages of plant growth by systemic or local infection (PATEL et al., 2014). Seeds are regarded as highly effective means for transporting plant pathogens over long distances (PATEL et al., 2014).

During the seed storage, many factors can affect the seed quality and the fungi viability, including temperature and relative humidity. Thus, correct storage conditions are fundamental for maintaining seed batch quality and studies on this topic should be made. The objective of the present study was to verify the health and physiological potential of soybean seeds submitted to different storage conditions.

\section{MATERIALS AND METHODS}

The experiments were done in the laboratories and greenhouse of the Departments of Phytopathology and Nematology and Crop Science of Escola Superior de Agricultura Luiz de Queiroz ESALQ/USP. Three batches of the Coodetec 206 soybean cultivar, with different vigor levels, were first evaluated for health and physiological quality and then stored for six months under the following conditions: cold chamber (temperature of $10^{\circ} \mathrm{C}$ and Relative humidity (RH) around 85\%), dry chamber $\left(20{ }^{\circ} \mathrm{C}\right.$ and $\mathrm{RH} \quad 50 \%$ ) and laboratory environment (no temperature or relative humidity control). Samples were analyzed every three months with the following tests:

\section{Determination of moisture content}

The oven method was used at $105{ }^{\circ} \mathrm{C}$, with two repetitions for each treatment as described in the Seed Analysis Rules (BRASIL, 2009).

\section{Health Test}

The blotter method was used to detect the fungi present on seeds (MATHUR \& KONGSDAL, 2003). Three wetted sheets of filter paper were placed in Petri plastic dishes ( $9 \mathrm{~cm}$ in diameter) and 10 soybean seeds were sowed, separated from each other. The Petri dishes were kept in incubation chamber at a temperature of $20 \pm$ 
$2{ }^{\circ} \mathrm{C}$ and alternating light (12 hours of white fluorescent light and 12 hours of dark) for seven days. The funghi evaluations were made with a stereoscopic microscope and also with an optical microscope when necessary.

\section{Germination Test}

Seeds were distributed on germination paper towel rolls, moistened with an amount of water equivalent to 2.5 times the weight of the dry substrate and placed to germinate at $25^{\circ} \mathrm{C}$ (BRASIL, 2009). Evaluations were made four and eight days after the beginning of the test, observing vigor at the first count and germination at the second count.

\section{Seedling emergence test in a greenhouse}

The seeds were sown in plastic boxes $(43 \times 30 \times 11 \mathrm{~cm})$, containing sterilized soil. The boxes were kept in a greenhouse and after seedling emergence, the number of normal seedlings emerging was noted. The emergence speed index and the total emerged seedlings were determined 14 days after the test began.

\section{Accelerated aging test}

The accelerated aging test was done according to a method described by Marcos Filho (1999). A single, uniform layer of seeds was placed on mesh inside plastic boxes $(11 \times 11 \times 3 \mathrm{~cm})$, containing $40 \mathrm{~mL}$ of water. The closed boxes were kept in aging chambers at $41{ }^{\circ} \mathrm{C}$ for $48 \mathrm{~h}$. After this period, the aged seeds were submitted to germinate according to germination test and evaluated after the fifth day (ISTA, 1985).

\section{Experimental design}

The experimental design was completely randomized for the laboratory tests and in completely randomized blocks for the greenhouse tests, with four repetitions of 50 seeds for each test. The results were analyzed using a factorial $3 \times 3$ design (storage time $\mathrm{x}$ storage conditions).

\section{RESULTS AND DISCUSSION}

The moisture contents of the three seed batches submitted to the three storage conditions were registered (Table 1). The seeds had a moisture content around $10 \%$ at the beginning of storage, which is considered ideal for maintaining the physiological potential of soybean seeds (MARCOS FILHO, 2005). After storing under laboratory conditions (uncontrolled environment), the moisture content remained around $9 \%$ for the three seed batches. Under the dry chamber conditions $\left(\mathrm{T}=20^{\circ} \mathrm{C}\right.$ and $\mathrm{RH}=50 \%$ ), the moisture contents fell to 5$6 \%$ and for the cold chamber $\left(\mathrm{T}=10{ }^{\circ} \mathrm{C}\right.$ and $\mathrm{RH}=85 \%$ ) were above $15 \%$.

The incidence of Phomopsis spp. in batches 1 and 2 showed a treatment variation 
due to the interaction between the environmental factors and storage time (Table 2). There was a reduction in Phomopsis occurrence after the third month, which became observable after 6 months under the laboratory and cold chamber conditions. Phomopsis spp. incidence in batch 3 was very low and did not show any variations which could be attributed to the interaction of the environmental and storage time factors, but a drop in incidence was observed after the third month. There was no variation in the occurrence of Cercospora kikuchii on soybean seeds due to the interaction of the storage time and environmental conditions but a reduction in fungal incidence was observed after the third month for batches 2 and 3 and at 6 months for batch 1 (Table 2).
Isolation frequences of Aspergillus spp. and Penicillium spp. frequently appear on soybean seeds (ANWAR et al. 2013). The behaviors of these storage fungi were similar to the others (Table 3). For Aspergillus spp., only batch 2 showed an interaction between time and storage environment factors, with a reduction in incidence after the third month in the cold chamber environment, which only differed significantly from the laboratory treatment. There was an interaction between these factors for Penicillium sp. for batches 1 and 3, with a smaller incidence in the dry chamber and laboratory treatments for batch 1 and only for the dry chamber for batch 3 . About the storage time, both fungi generally showed, the same reduction in the sixth month of storage.

Table 1. Moisture content of three soybean seed batches stored in three environments conditions for six months (Piracicaba, 2011).

\begin{tabular}{ccccc}
\hline \multirow{2}{*}{ Batch } & & \multicolumn{3}{c}{ Storage period } \\
\cline { 3 - 5 } 1 & Environment & Start & 3 months & 6 months \\
\cline { 3 - 5 } 1 & U.E. & 10.05 & 8.98 & 9.47 \\
& D.C. & 10.05 & 7.27 & 5.63 \\
& C.C. & 10.05 & 15.56 & 16.27 \\
\hline \multirow{2}{*}{2} & U.E. & 10.40 & 8.81 & 8.61 \\
& D.C. & 10.40 & 6.91 & 5.14 \\
& C.C. & 10.40 & 17.16 & 14.91 \\
\multirow{2}{*}{3} & U.E. & 10.18 & 9.46 & 9.24 \\
& D.C. & 10.18 & 6.75 & 5.65 \\
& C.C. & 10.18 & 15.52 & 16.48 \\
\hline
\end{tabular}

*U.E. $=$ uncontrolled environment (laboratory); D.C. $=$ dry chamber; C.C. $=$ cold chamber 
Table 2. Incidence (\%) of field fungi in three soybean seed batches stored in three environments conditions for six months (Piracicaba, 2011).

\begin{tabular}{|c|c|c|c|c|c|c|c|c|c|}
\hline \multirow{3}{*}{ Batches } & \multirow{3}{*}{ Environment* } & \multicolumn{4}{|c|}{ Phomopsis spp. } & \multicolumn{4}{|c|}{ Cercospora kikuchii } \\
\hline & & \multicolumn{4}{|c|}{ Storage period (months) } & \multicolumn{4}{|c|}{ Storage period (months) } \\
\hline & & Start & 3 & 6 & Mean & Start & 3 & 6 & Mean \\
\hline \multirow{4}{*}{1} & U.E. & 31 & 13 & 1 & $15.0 b^{* *}$ & 5 & 1 & 0 & $2.0^{\mathrm{ns}}$ \\
\hline & D.C. & 31 & 18 & 20 & $23.3 \mathrm{a}$ & 5 & 3 & 1 & 2.7 \\
\hline & C.C. & 31 & 10 & 6 & $15.7 b$ & 5 & 3 & 0 & 3.0 \\
\hline & Mean & $31.0 \mathrm{~A}$ & 13.7B & $9.0 \mathrm{C}$ & & $5 \mathrm{~A}$ & $2 \mathrm{~A}$ & $0.3 \mathrm{~B}$ & \\
\hline $\mathrm{CV}$ & \multicolumn{5}{|c|}{$16.7 \%$} & \multicolumn{3}{|c|}{$58.1 \%$} & \\
\hline \multirow{4}{*}{2} & U.E. & 24 & 15 & 0 & $13.0 \mathrm{~b}$ & 4 & 0 & 0 & $1.3 b$ \\
\hline & D.C. & 24 & 20 & 15 & $19.7 \mathrm{a}$ & 4 & 2 & 1 & $2.3^{\mathrm{a}}$ \\
\hline & C.C. & 24 & 11 & 6 & $13.7 b$ & 4 & 2 & 1 & $2.3^{\mathrm{a}}$ \\
\hline & Mean & $24 \mathrm{~A}$ & $15.3 \mathrm{~B}$ & $7.0 \mathrm{C}$ & & $4 \mathrm{~A}$ & $1.3 \mathrm{~B}$ & $0.7 \mathrm{~B}$ & \\
\hline $\mathrm{CV}$ & \multicolumn{5}{|c|}{$22.0 \%$} & \multicolumn{3}{|c|}{$44.6 \%$} & \\
\hline \multirow{4}{*}{3} & U.E. & 8 & 5 & 0 & $4.3^{\mathrm{ns}}$ & 7 & 0 & 0 & $2.3 b$ \\
\hline & D.C. & 8 & 5 & 4 & 5.6 & 7 & 4 & 2 & $4.3^{\mathrm{a}}$ \\
\hline & C.C. & 8 & 4 & 2 & 4.6 & 7 & 0 & 0 & $2.3 \mathrm{ab}$ \\
\hline & Mean & $8.0 \mathrm{~A}$ & $4.6 \mathrm{~B}$ & $2.0 \mathrm{~B}$ & & $7.0 \mathrm{~A}$ & $1.0 \mathrm{~B}$ & $0.7 \mathrm{~B}$ & \\
\hline $\mathrm{CV}$ & & & $47.0 \%$ & & & & $84.4 \%$ & & \\
\hline
\end{tabular}

*U.E. $=$ uncontrolled environment (laboratory); D.C. $=$ dry chamber; C.C. $=$ cold chamber

**Means followed by small letters in the columns and capital letters in the rows differ among themselves according to the Tukey test at the $5 \%$ probability level; ns = not significant 
Table 3. Incidence (\%) of storage fungi in three soybean seed batches stored in three environments conditions for six months (Piracicaba, 2011).

\begin{tabular}{|c|c|c|c|c|c|c|c|c|c|}
\hline \multirow{3}{*}{ Batches } & \multirow{3}{*}{ Environment* } & \multicolumn{4}{|c|}{ Aspergillus spp. } & \multicolumn{4}{|c|}{ Penicillium sp. } \\
\hline & & \multicolumn{4}{|c|}{ Storage period (months) } & \multicolumn{4}{|c|}{ Storage period (months) } \\
\hline & & Start & 3 & 6 & Mean & Start & 3 & 6 & Mean \\
\hline \multirow{4}{*}{1} & U.E. & 72 & 57 & 69 & $66.0^{\mathrm{ns} * *}$ & 63 & 27 & 17 & $35.7 b$ \\
\hline & D.C. & 72 & 69 & 54 & 65.0 & 63 & 56 & 21 & $46.7 b$ \\
\hline & C.C. & 72 & 73 & 31 & 58.7 & 63 & 91 & 88 & $80.7 \mathrm{a}$ \\
\hline & Mean & $72 \mathrm{~A}$ & $66.3 \mathrm{~A}$ & $48.6 \mathrm{~B}$ & & $63 \mathrm{~A}$ & $58.0 \mathrm{~A}$ & $42.0 \mathrm{~B}$ & \\
\hline $\mathrm{CV}$ & \multicolumn{5}{|c|}{$10.1 \%$} & \multicolumn{3}{|c|}{$16.0 \%$} & \\
\hline \multirow{4}{*}{2} & U.E. & 63 & 62 & 63 & $62.7 \mathrm{a}$ & 68 & 45 & 44 & $52.3^{\text {ns }}$ \\
\hline & D.C. & 63 & 59 & 47 & $56.3 \mathrm{ab}$ & 68 & 37 & 36 & 47.0 \\
\hline & C.C. & 63 & 44 & 39 & $48.7 \mathrm{~b}$ & 68 & 51 & 61 & 60.0 \\
\hline & Mean & $63 \mathrm{~A}$ & $55 \mathrm{AB}$ & $49.7 \mathrm{~B}$ & & $68 \mathrm{~A}$ & 44.3B & $35.2 \mathrm{~B}$ & \\
\hline $\mathrm{CV}$ & \multicolumn{5}{|c|}{$15.1 \%$} & \multicolumn{3}{|c|}{$20.6 \%$} & \\
\hline \multirow{4}{*}{3} & U.E. & 3 & 10 & 4 & $5.7^{\mathrm{ns}}$ & 55 & 66 & 13 & $44.7 \mathrm{a}$ \\
\hline & D.C. & 3 & 5 & 4 & 4.0 & 55 & 27 & 10 & $30.7 b$ \\
\hline & C.C. & 3 & 4 & 1 & 2.7 & 55 & 55 & 52 & $54.0 \mathrm{a}$ \\
\hline & Mean & $3.0^{\mathrm{NS}}$ & 6.3 & 3.0 & & $55.0 \mathrm{~A}$ & $49.3^{\mathrm{a}}$ & $25.0 \mathrm{~B}$ & \\
\hline $\mathrm{CV}$ & & & $62.5 \%$ & & & & $156.2 \%$ & & \\
\hline
\end{tabular}

*U.E. $=$ uncontrolled environment (laboratory); D.C. $=$ dry chamber; C.C. $=$ cold chamber

**Means followed by small letters in the columns and capital letters in the rows differ among themselves according to the Tukey test at the $5 \%$ probability level; ns $=$ not significant in the column and NS= not significant in the row 
About the seed physiological potential, the values for the first germination count, germination and accelerated aging are shown in Table 4. In all the batches, the germination after three months storage increased, which was maintained until six months. Batch 1 showed higher percentage seed germination under laboratory conditions when compared to the cold chamber.

As observed for germination, tests based on seedling growth, first germination count (Table 4) and seedling emergence speed (Table 5), showed increases in vigor after three months storage, which were maintained until the sixth month. However, there were no variations due an interaction between environmental factors and storage time and no reduction in seed vigor was observed based on seedling percentage emergence after storage.

For the accelerated aging test (Table 4), an interaction between the time and storage environment factors was only observed for batches 2 and 3, with a reduction in vigor after three months storage. Batch 1 seeds stored under laboratory and dry chamber conditions, showed a higher vigor compared to those stored in the cold chamber. For batch 2, the highest vigor was observed for those seeds stored in the dry chamber whereas for batch 3 , the conditions in the dry and cold chambers favored the maintenance of seed vigor.

The high relative humidity of the cold chamber caused an increase in seed moisture, which adversely affected the conservation of the physiological potential, even at low temperatures. When the seed moisture content, relative humidity and temperatures are maintained in low levels, physiological potential will be better conserved (MINOR \& PASCHAL, 1982), with the relative humidity being more critical than the temperature (MARCOS FILHO, 2005).

The results obtained for the field fungi, Phomopsis spp. and C. kikuchii were expected, because these fungi require a moisture content around $25 \%$ for their survival (AGARWAL \& SINCLAIR, 1996) and as the moisture content falls, these pathogens lose their viability.

The most important factors influencing infection by storage fungi are the seed moisture content, environmental relative humidity, temperature and storage time (DHINGRA, 1985). For these fungi, there is a tendency for an increase in the incidence with increasing storage time since these fungi are adapted to storage conditions (CARVALHO \& NAKAGAWA, 2000). 
Table 4. Germination and accelerated aging of three soybean seed batches stored in three environments conditions for six months (Piracicaba, 2011).

\begin{tabular}{|c|c|c|c|c|c|c|c|c|c|c|c|c|c|}
\hline \multirow{3}{*}{ Batch } & \multirow{3}{*}{ Environment* } & \multirow{2}{*}{\multicolumn{4}{|c|}{$\begin{array}{l}\text { First germination count } \\
\text { Storage period (months) }\end{array}$}} & \multirow{2}{*}{\multicolumn{4}{|c|}{$\begin{array}{l}\text { Percentage germination } \\
\text { Storage period (months) }\end{array}$}} & \multirow{2}{*}{\multicolumn{4}{|c|}{$\begin{array}{c}\text { Accelerated aging } \\
\text { Storage period (months) }\end{array}$}} \\
\hline & & & & & & & & & & & & & \\
\hline & & Start & 3 & 6 & Mean & Start & 3 & 6 & Mean & Start & 3 & 6 & Mean \\
\hline \multirow{4}{*}{1} & U.E. & 63 & 79 & 81 & $74^{\mathrm{ns}^{* *}}$ & 79 & 88 & 92 & $86 a$ & 67 & 72 & 60 & $66 a$ \\
\hline & D.C. & 63 & 86 & 74 & 74 & 79 & 90 & 84 & $84 \mathrm{ab}$ & 67 & 54 & 82 & $68 \mathrm{a}$ \\
\hline & C.C. & 63 & 81 & 66 & 70 & 79 & 86 & 80 & $82 \mathrm{~b}$ & 67 & 53 & 49 & $56 \mathrm{~b}$ \\
\hline & Mean & $63 \mathrm{C}$ & $82 \mathrm{~A}$ & 74B & & 79B & $88 \mathrm{~A}$ & $85 \mathrm{~A}$ & & $67^{\mathrm{NS}}$ & 60 & 64 & \\
\hline $\mathrm{CV}$ & & \multicolumn{4}{|c|}{$6.8 \%$} & \multicolumn{4}{|c|}{$5.6 \%$} & \multicolumn{4}{|c|}{$11.1 \%$} \\
\hline \multirow{4}{*}{2} & U.E. & 80 & 82 & 79 & $80^{\mathrm{ns}}$ & 80 & 88 & 86 & $85^{\mathrm{ns}}$ & 67 & 67 & 46 & $60 \mathrm{~b}$ \\
\hline & D.C. & 80 & 82 & 84 & 82 & 80 & 84 & 90 & 85 & 67 & 61 & 80 & $69 a$ \\
\hline & C.C. & 80 & 84 & 85 & 83 & 80 & 88 & 89 & 86 & 67 & 39 & 64 & $57 \mathrm{~b}$ \\
\hline & Mean & $80 \mathrm{~B}$ & $83 \mathrm{~A}$ & $83 \mathrm{~A}$ & & $80 \mathrm{~B}$ & $87 \mathrm{~A}$ & $88 \mathrm{~A}$ & & $67 \mathrm{~A}$ & $56 \mathrm{~B}$ & $63 \mathrm{AB}$ & \\
\hline $\mathrm{CV}$ & & \multicolumn{4}{|c|}{$8.2 \%$} & \multicolumn{3}{|c|}{$10.1 \%$} & \multicolumn{5}{|c|}{$10.4 \%$} \\
\hline \multirow{4}{*}{3} & U.E. & 78 & 90 & 87 & $83^{\mathrm{ns}}$ & 88 & 95 & 91 & $91^{\mathrm{ns}}$ & 67 & 49 & 33 & $50 \mathrm{~b}$ \\
\hline & D.C. & 78 & 91 & 89 & 86 & 88 & 95 & 93 & 92 & 67 & 56 & 69 & $64 a$ \\
\hline & C.C. & 78 & 92 & 92 & 87 & 88 & 94 & 95 & 92 & 67 & 48 & 60 & $58 \mathrm{a}$ \\
\hline & Mean & $78 \mathrm{~B}$ & $91 \mathrm{~A}$ & $89 \mathrm{~A}$ & & $88 \mathrm{~B}$ & $95 \mathrm{~A}$ & $93 \mathrm{~A}$ & & $67 \mathrm{~A}$ & $51 \mathrm{~B}$ & $54 \mathrm{~B}$ & \\
\hline $\mathrm{CV}$ & & & $4.6 \%$ & & & & $6.0 \%$ & & & & $9.5 \%$ & & \\
\hline
\end{tabular}

*U.E. $=$ uncontrolled environment (laboratory); D.C. $=$ dry chamber; C.C. $=$ cold chamber

**Means followed by small letters in the columns and capital letters in the rows differ among themselves according to the Tukey test at the 5\% probability level; $\mathrm{ns}=$ not significant in the column and $\mathrm{NS}=$ not significant in the row 
Table 5. Speed and percentage emergence of three batches of soybean seeds stored in three environments conditions for six months (Piracicaba, 2011).

\begin{tabular}{|c|c|c|c|c|c|c|c|c|c|}
\hline \multirow{3}{*}{ Batches } & \multirow{3}{*}{ Environment* } & \multicolumn{4}{|c|}{ Emergence speed } & \multicolumn{4}{|c|}{ Percentage emergence } \\
\hline & & \multicolumn{4}{|c|}{ Storage period (months) } & \multicolumn{4}{|c|}{ Storage period (months) } \\
\hline & & Start & 3 & 6 & Mean & Start & 3 & 6 & Mean \\
\hline \multirow{4}{*}{1} & U.E. & 6.5 & 7.4 & 8.0 & $6.8^{\mathrm{ns}^{* *}}$ & 88 & 80 & 88 & $85^{\mathrm{ns}}$ \\
\hline & D.C. & 6.5 & 8.2 & 7.3 & 7.0 & 88 & 87 & 88 & 88 \\
\hline & C.C. & 6,5 & 7.8 & 7.1 & 6.6 & 88 & 84 & 88 & 87 \\
\hline & Mean & $6.5^{\mathrm{NS}}$ & 7.8 & 7.5 & & $88^{\mathrm{NS}}$ & 84 & 88 & \\
\hline $\mathrm{CV}$ & \multicolumn{5}{|c|}{$12.7 \%$} & \multicolumn{3}{|c|}{$31.3 \%$} & \\
\hline \multirow{4}{*}{2} & U.E. & 4.8 & 7.7 & 4.4 & $5.6^{\mathrm{ns}}$ & 87 & 79 & 47 & $71^{\mathrm{ns}}$ \\
\hline & D.C. & 4.8 & 7.0 & 8.7 & 6.8 & 87 & 82 & 90 & 86 \\
\hline & C.C. & 4.8 & 7.4 & 8.6 & 6.9 & 87 & 89 & 88 & 88 \\
\hline & Mean & $4.8 \mathrm{~B}$ & $7.4 \mathrm{~A}$ & $7.2^{\mathrm{a}}$ & & $87^{\mathrm{NS}}$ & 83 & 75 & \\
\hline $\mathrm{CV}$ & \multicolumn{5}{|c|}{$32.5 \%$} & \multicolumn{3}{|c|}{$24.9 \%$} & \\
\hline \multirow{4}{*}{3} & U.E. & 5.1 & 8.1 & 8.8 & $7.3^{\mathrm{ns}}$ & 86 & 96 & 90 & $91^{\mathrm{ns}}$ \\
\hline & D.C. & 5.1 & 7.1 & 8.2 & 6.6 & 86 & 84 & 91 & 87 \\
\hline & C.C. & 5.1 & 7.9 & 7.6 & 6.9 & 86 & 88 & 80 & 85 \\
\hline & Mean & $5.1 \mathrm{~B}$ & $7.7 \mathrm{~A}$ & $8.2 \mathrm{~A}$ & & $86^{\mathrm{NS}}$ & 89 & 87 & \\
\hline $\mathrm{CV}$ & & & $16.3 \%$ & & & & $1.6^{\circ}$ & & \\
\hline
\end{tabular}

*U.E. $=$ uncontrolled environment (laboratory); D.C. $=$ dry chamber; C.C. $=$ cold chamber

**Means followed by small letters in the columns and capital letters in the rows differ among themselves according to the Tukey test at the $5 \%$ probability level; ns= not significant in the column and $\mathrm{NS}=$ not significant in the row. 
However, the results obtained in this experiment showed a reduction in the level of these fungi incidence, probably as a result of the variation in the seed moisture content. Tanaka et al. (2001) obtained the same result for Aspergillus spp. in some corn batches, observing a tendency for reduction in seeds stored in a cold chamber. For Penicillium spp., these authors observed an increase, which was smaller in the cold chamber.

Under the laboratory and dry chamber conditions there was a reduction in seed moisture content, which was greater for the dry chamber, reaching around 5.5\% after six months storage, which is below the ideal for the development of these fungi. According to Agarwal \& Sinclair (1996), the moisture content necessary for the growth of storage fungi varies from $12-18 \%$ for soybeans depending on the fungus species.

Marcos Filho (2005) has showed that seed germinative potential decreases with time as a part of the natural deterioration process of seeds. However, the opposite was observed in this experiment, possibly due to the significant reduction in the incidence of Phomopsis spp., Aspergillus spp. and Penicillium sp., considered as seed rotting agents.

Fungi growing on the stored grains reduce the germination rate, carbohydrate, protein, total oil content, increase moisture content and also enhancing other biochemical changes of seeds (BHATTACHARYA \& RAHA, 2002). Seeds can be deteriorated by the action of the storage fungi Aspergillus spp. and Penicillium spp. Tanaka \& Corrêa (1981) proved this by inoculating bean seeds with these fungi and storing them for 16 months; after this period, the seeds, which initially had a germinative potential of $81 \%$, showed $60 \%$ germination for non-inoculated seeds and $40 \%$ and $32 \%$ for those inoculated with Aspergillus sp. and Penicillium sp., respectively. Most of the species of Aspergillus are dominant and play vital role in the seed biodeterioration, reducing seed germination and vigor (CHAVAN, 2011; ROCHA et al., 2014).

Waint-Tassi et al. (2012) observed reduction in the physiological potential of seed with a high incidence of Phomopsis sp. However, in seeds stored under favorable conditions, the fungi rapidly lost its viability and this improved laboratory germination results. Other authors also have verified an increase in seed vigor and germination after 60 days storage together with a reduction in the incidence of Phomopsis sp. (MARTINS FILHO et al., 2001). 
The increase in seed vigor observed in the tests based on seedling growth (first germination count and emergence speed), may also be due to a reduction in the occurrence of the main pathogens associated with the seeds until the sixth month of storage. The seedling emergence test did not indicate any increase in vigor after storage, agreeing with those results obtained by Henning (1987). This author found that the adverse effect of Phomopsis spp. on germination was not repeated for seedlings emerging from these seeds. This may be explained by the pathogens being present principally on the seed coat, which remains in the soil after seedling emergence.

The accelerated aging test confirms that after storage, seed physiological potential is reduced and seeds cannot withstand the stress conditions they are submitted to during accelerated aging test It shows that, even in the seed coat, the fungi probably affect the biochemical protection mechanism in seeds. The fungi biochemical action is related to enzyme involved in the plant cell wall degradation and in the toxins production which will cause decomposition of viable tissues, thereby causing an increase in respiratory rate of the seed host, resulting in seed deterioration (HENNING et al., 2009).
Thus, the results of lower germination and vigor obtained from the remaining tests at the beginning of storage are associated with the high incidence of pathogens such as Phomopsis spp., Aspergillus spp. and Penicillium sp.

\section{CONCLUSION}

There is a reduction in field and storage fungi occurrence in soybean seeds with storage, especially for the conditions of the cold chamber and the uncontrolled laboratory environment, resulting in the increase of germination and seedling emergence.

\section{REFERENCES}

AGARWAL, V.K.; SINCLAIR, J.B. 1996. Principles of seed pathology, Boca Raton: CRC Press, $2^{\text {nd }}$ ed. $168 \mathrm{p}$.

ANWAR, S.A.; RIAZ, S.; AHMAD, C.A.; SUBHANI, M.N.; CHATTHA, M.B. 2013. Mycoflora associated with stored seeds of soybean. Mycopathology, Reno, v. 11, n.2, p. 85-90.

BRASIL. 2009. Ministério da Agricultura, Pecuária e Abastecimento. Regras para análise de sementes, Brasília: MAPA/ACS, Secretaria de Defesa Agropecuária. 395p.

BHATTACHARYA, K.; RAHA, S. 2002. Deteriorative changes of maize, groundnut and soybean seeds by fungi in storage. Mycopathologia, Reno, v. 155, p.135-141. 
CARVALHO, N. M.; NAKAGAWA, J. 2000. Sementes: ciência, tecnologia e produção. Jaboticabal: FUNEP. 588 p.

CATÃO, H. C. R. M.; MAGALHÃES, H. M.; SALES, N. L. P.; BRANDÃO JUNIOR, D. S.; ROCHA, F. S. 2013. Incidência e viabilidade de sementes crioulas de milho naturalmente infestadas com fungos em pré e pós-armazenamento. Ciência Rural, Santa Maria, v.43, n.5, p. 764-770.

CONAB. Companhia Nacional de Abastecimento. 2015. Acompanhamento da safra brasileira: grãos, safra 2013/2014, terceiro levantamento. Disponível em: < http://www.conab.gov.br/OlalaCMS/uploads /arquivos/13_12_10_16_06_56_boletim_por tugues_dezembro_2013.pdf $>$. Acesso em: Jun de 2015.

CHAVAN, A.M. 2011. Nutritional changes in oilseeds due to Aspergillus spp. Journal of Experimental Science, Vallakkadavu, v.2, p. 29-31.

DHINGRA, O. 1985. Prejuízos causados por microrganismos durante o armazenamento de sementes. Revista Brasileira de Sementes, Pelotas, v.7, n.1, p.139-146.

DOMINJAN, A., FERAICA, M., JURJEVIC, Z., IVIL D., CVJETKOVIC, B. 2005. Fumonisin $B_{1}$, fumonisin $B_{2}$, zearalenone and ochratoxin A contamination of maize in Croatia. Food Additives and Contaminants, Abingdon, v. 22, n.7, p.677680.

GALLI, J. A.; PANIZZI, R. C.; VIEIRA, R. D. 2007. Efeito de Colletotrichum dematium var. truncata e Phomopsis sojae na qualidade sanitária e fisiológica nas sementes de soja. Summa Phytopathologica, Botucatu, v. 33, n. 1, p. 40-46.

HENNING, F. A.; MERTZ, L. M.; ZIMMER, P. D.; TEPLIZKY, M. D. F. 2009. Qualidade fisiológica, sanitária e análise de izoenzimas de sementes de aveia preta tratadas com diferentes fungicidas. Revista Brasileira de Sementes, Londrina, v. 31, n. 9, p. 63-69.

HENNING, A.A. 1987. Testes de sanidade e sementes de soja. (Eds. J. Soave and M.M.V.S. Wetzel), Campinas: Fundação Cargill, p.441-454.

ISTA. International Seed Testing Association. 1985. International rules of seed testing. Seed Science and Technology, Zurich, v.13, p.299-513.

ITO, M.F.; CASTRO, J.L.; MENTEN, J.O.M.; MORAES, M.H.D. 2003. Importância do uso de sementes sadias de feijão e tratamento químico. O Agronômico, Campinas, v.55, p.14-16.

KROHN, N. G.; MALAVASI, M. M. 2004. Qualidade fisiológica de sementes de soja tratadas com fungicidas durante e após o armazenamento. Revista Brasileira de Sementes, Pelotas, v. 26, n. 2, p. 91-97.

MARCOS FILHO, J. 1999. Teste de envelhecimento acelerado. In: KRZYZANOWSKI F.C. VIEIRA, R.D.; FRANÇA NETO J.B. (Ed.). Vigor de sementes: conceitos e testes, Londrina: ABRATES, pp.1-24.

MARCOS FILHO, J. 2005. Fisiologia de sementes de plantas cultivadas. Piracicaba: FEALQ. 495p.

MARTINS FILHO, S.; LOPES, J.C.; RANGEL, O.J.P.; TAGLIAFERRE, C. 2001. Avaliação da qualidade físiológica de sementes de soja armazenadas em condições de ambiente natural em Alegre - ES. Revista Brasileira de Sementes, Londrina, v.23, n.2, p.201-208.

MATHUR, S.B.; KONGSDAL, O. 2003. Common laboratory seed healthy testing methods for detecting fungi, Copenhagen: International Seed Testing Association. $425 \mathrm{p}$. 
MINOR, H.C.; PASCHAL, E.H. 1982. Variation in storability of soybeans under stimulated tropical conditions. Seed Science and Technology, Zurich, v.10, p.131-139.

PATEL, R.; PATEL, D.R.; PANDEY, A.K. 2014. Study on seed borne mycoflora of soybean, sorghum and groundnut of different zones of Madhya Pradesh. International journal of Plant protection, Ghaziabad, v.7, n.1, p. 9-14.

RATHOD, L.R.; PAWAR, P.V. 2012. Antimicrobial activity of medicinal plant to control seed borne pathogen of soybean. Current botany, Kerala,v.3, n. 2, p. 10-12.

ROCHA, F.S.; CATÃO, H.C.R.M.; BRANDÃO, A.A.; GOMES, L.A.A. 2014. Danos causados por diferentes potenciais de inóculo de Aspergillus ochraceus no vigor de sementes de soja. Semina, Ciências agrárias, Londrina, v.35, n.6, p. 2895-2904.

TANAKA, M.A.S.; CORRÊA, M.V. 1981. Influência de Aspergillus e Penicillium no armazenamento de sementes de feijão (Phaseolus vulgaris L.). Fitopatologia Brasileira, Brasilia, v.6, p.451-456.

TANAKA, M.A.S.; MAEDA, J.A.; PLAZAS, I.H.A.Z. 2001. Microflora fúngica de sementes de milho em ambientes de armazenamento. Scientia Agricola, Piracicaba, v.58, n.3, p.501-508.

WAIN-TASSI, A.L.; SANTOS, J.F.; PANIZZI, R.C.; VIEIRA, R.D. 2012. Seedborne pathogens and electrical conductivity of soybean seeds. Scientia Agricola, Piracicaba, v. 26, n. 1, p. 19-25.

Recebido em: 31/7/2015 Aceito para publicação em: 24/2/2016 